\title{
Borrowing and shift-induced interference: contrasting patterns in French-Germanic contact in Brussels and Strasbourg
}

Article

Accepted Version

paper

Treffers-Daller, J. (1999) Borrowing and shift-induced interference: contrasting patterns in French-Germanic contact in Brussels and Strasbourg. Bilingualism: Language and Cognition, 2 (1). pp. 1-22. ISSN 1469-1841 Available at https://centaur.reading.ac.uk/29892/

It is advisable to refer to the publisher's version if you intend to cite from the work. See Guidance on citing.

Published version at: http://journals.cambridge.org/action/displayAbstract?fromPage=online\&aid=51991

Publisher: Cambridge University Press

All outputs in CentAUR are protected by Intellectual Property Rights law, including copyright law. Copyright and IPR is retained by the creators or other copyright holders. Terms and conditions for use of this material are defined in the End User Agreement.

$\underline{\text { www.reading.ac.uk/centaur }}$ 
Central Archive at the University of Reading

Reading's research outputs online 
Borrowing and shift-induced interference: contrasting patterns in French-Germanic contact in Brussels and Strasbourg ${ }^{1}$

Jeanine Treffers-Daller

University of the West of England

Faculty of Languages and European Studies

Frenchay Campus

Coldharbour lane

Bristol BS16 1QY

email: Jeanine.Treffers-Daller@uwe.ac.uk 



\section{Abstract}

The main aim of the present article is to test hypotheses derived from the model for contactinduced language change as formulated in Thomason and Kaufman (1988 et seq.). As the model correctly predicts the asymmetries between the mutual influences of the Germanic and the Romance varieties in Brussels and Strasbourg it is a very powerful tool for describing the contact patterns in these cities. The analysis shows that the contact patterns are very similar, both from a quantitative and from a qualitative point of view, despite important differences in the sociolinguistic situation of both cities. The striking similarities in the outcome of language contact seem to find a plausible explanation in the fact that the language contact situations in both cities are similar from a typological point of view: in each city a variety of French is in contact with a Germanic variety (Alsatian and Brussels Dutch). Thus, the claim of the present article is that the structure of the languages plays a more prominent role in the outcome of language contact than the sociolinguistic history of the speakers. 
The aim of the present article is, in the first place, to test hypotheses derived from the model for contact-induced language change as formulated in Thomason and Kaufman (1988 et seq.). The framework can be shown to correctly predict the basic asymmetries of the contact patterns in Brussels and Strasbourg and is thus an invaluable tool for describing these patterns.

In the second place, the article aims at showing how an analysis of the similarities and the differences between two language contact situations can contribute towards a further understanding of variability in this domain of research. More specifically a comparison of the language contact phenomena in Strasbourg and Brussels can shed light upon the debate around the nature of the constraints on contact-induced change. Thomason and Kaufman (1988: 35) take a clear point of view in this discussion, when they say "it is the sociolinguistic history of the speakers, and not the structure of their language, that is the primary determinant of the linguistic outcome of language contact." This article shows that despite the differences in the sociolinguistic situation of Brussels and Strasbourg, the overall contact patterns are very similar, both from a quantitative and from a qualitative point of view. Thus, the present article provides some evidence for the view that it is the structure of the languages involved rather than the sociolinguistic history of the speakers, which determines the outcome of language contact in the first place.

Brussels and Strasbourg form a very interesting test case for Thomason and Kaufman's model, because the authors do not discuss these contact situations in their book at all. Thus, their model is not based upon an analysis of the contact patterns in these cities. This makes it possible to genuinely test the predictions of the model against the data available 
from Brussels and Strasbourg. Thomason and Kaufman's model provides a framework within which the results of a large number of descriptive studies about language contact in Belgium and Alsace can be summarised and evaluated. To my knowledge no efforts have been made until now to compare the mutual influences in these areas, apart from the analyses presented in Treffers-Daller (1995). This article wants to contribute towards a more general perspective on language contact along the Romance-Germanic language frontier.

\section{Thomason and Kaufman's model}

The article focuses on the contrastive effects of two types of interference which Thomason and Kaufman (henceforth $\mathrm{T} \& \mathrm{~K}$ ) have called borrowing and shift-induced interference. Borrowing is defined as the "incorporation of foreign features into a group's native language of that language: the native language is maintained but is changed by the addition of the incorporated features" (T\&K: 37). Shift-induced change, on the other hand, "results from imperfect group learning during a process of language $\operatorname{shift}^{2}(\mathrm{~T} \& \mathrm{~K}: 38)$. As the model is well known, I will only draw attention to the following predictions of the model, which are

particularly important for the present paper. The authors of the model claim that "in a borrowing situation, the first foreign elements to enter the borrowing language are words. If there is long-term cultural pressure from the source-language speakers on the borrowinglanguage-speaker group, then structural features may be borrowed as well - phonological, phonetic and syntactic elements, and even (though more rarely) features of the inflectional 
morphology" (T\&K: 37). Interference through imperfect group learning, on the other hand, "does not begin with vocabulary: it begins with sounds and syntax" (T\&K: 38).

$\mathrm{T} \& \mathrm{~K}$ recognise that it is very difficult to predict exactly how social factors influence the outcome of language contact. Their focus is, in the first place, "on systematising the linguistic facts, rather than on the various kinds of social influences." (T\&K: 36). In their view the information available about the social circumstances in which language contact takes place does not allow to make broad generalisations about the effect of social factors on the linguistic outcomes of language contact. As mentioned above, intensity of contact is considered to have at least some predictive value in combination with linguistic factors such as typological distance between the languages in contact. The following quotation gives some insight into T\&K's view of the social conditioning of language contact in a borrowing situation.

"Greater intensity of contact in general means more borrowing, though attitudes (especially, maybe, those fostered by a well-established standard dialect of the wouldbe borrowing language) can hinder structural borrowing to some extent. The major factors that promote greater intensity of contact, or greater cultural pressure on borrowing-language speakers are these: length of time - enough time for bilingualism to develop and for interference features to make their way into the borrowing language; many more source-language speakers than borrowing-language speakers; and either socio-political dominance of source-language speakers over borrowing- 
language speakers or intimate contact in mixed households and/or other social settings." (T\&K: 72)

Thomason (1998: 3) adds that" great intensity of contact is a necessary condition for certain kinds of interference, especially structural interference, but it is by no means a sufficient condition." Thus, one can find contact situations in which despite great pressure on speakers of one language, very little contact-induced change has occurred. One such example is according to Thomason (1998) language contact between English and Montana Salish (also called Flathead), a Salishan language spoken in north-western Montana.

The contrastive effects of borrowing and interference distinguished above can very clearly be shown in Brussels and Strasbourg, where the influence of the Romance varieties on the Germanic varieties is mainly visible in the lexicon, and the Germanic varieties have primarily exerted influence on the phonology and syntax of the Romance varieties. The hypotheses tested in this article can be summarised as follows.

In the first place, it is claimed that the language contact phenomena found in Brussels Dutch and in Alsatian as spoken in Strasbourg are the result of a borrowing process, whereas the contact phenomena found in the French varieties in these cities are manifestations of shiftinduced interference.

In the second place, it is assumed that lexical influence from French is important in the Germanic varieties (Brussels Dutch and Alsatian as spoken in Strasbourg) whereas lexical influence in the opposite direction (from the Germanic varieties in the French varieties) is far 
less significant. Interlingual structural influences on the level of phonology and syntax, on the contrary, will be more prominent in the French varieties.

In the third place, the article wants to test the claim that morphological interference remains limited in comparison to interference on the level of syntax and phonology (T\&K: $38)$.

The predictions of the model can be summarised as follows in Table 1 .

- Insert Table 1 about here -

The analysis is based on a comparison between the French-Dutch corpus described in Treffers-Daller (1994) and the Alsatian-French corpus described in Gardner-Chloros (1991) ${ }^{3}$. Moreover, extensive reference is made to the literature about both cities

\section{A sociolinguistic comparison between Brussels and Strasbourg}

This section gives an overview of some of the main similarities and differences between the sociolinguistic situation of Brussels and Strasbourg. The language contact situation in these cities are comparable because in both cities French is in contact with a Germanic variety that is less prestigious than French. In both cities bilingualism is asymmetrical in that the speakers 
of Alsatian and of Brussels Dutch are more likely to learn French than vice versa. Contrary to what I have said in an earlier paper (Treffers-Daller 1995), however, I believe that these two cities are only superficially similar, from a sociolinguistic point of view. A careful analysis of the facts shows that there are major differences between Brussels and Strasbourg on a number of points that $\mathrm{T} \& \mathrm{~K}$ consider to have predictive value for the amount and the depth of borrowing or interference one finds in a speech community, namely: a high level of bilingualism, length of contact, relative sizes of speaker populations and socio-economic and/or political dominance of source-language speakers over borrowing-language speakers. T\&K also point out that well-established standard dialects of the borrowing language can hinder structural borrowing to some extent. All these factors relate to the macrosociolinguistic level of analysis rather than the micro-sociolinguistic level. In previous work (Treffers-Daller 1994) I have shown that micro-sociolinguistic factors such as social networks, neighbourhood of residence, age and choice of a French or a Dutch school have a bearing upon the frequency with which individuals display the language contact features that are being discussed below. This paper focuses on the differences between two speech communities rather than on differences between individuals or groups of speakers within each of the two bilingual communities and therefore takes a macro-sociolinguistic rather than a micro-sociolinguistic perspective on language contact. A discussion of the complex interaction between macro- and micro-sociolinguistic factors in language contact - however important - is beyond the scope of the present investigation. 


\section{Generalities}

With over 900.000 inhabitants, Brussels-Capital, which consists of nineteen communes, is clearly a larger city than Strasbourg, with about 250.000 inhabitants. The latter nevertheless functions as the regional capital and has, just like Brussels, an important role as the seat of European organisations. Both cities are situated on the Germanic side of the RomanceGermanic linguistic frontier, one in Belgium and one in France. It is important to point to the fact that Brussels is officially a bilingual city, with Standard Dutch and French as its official languages, whereas in Strasbourg only French has official status. Also, Strasbourg is separated by a national frontier from the area in which Standard German has official status. The nineteen municipalities of Brussels form a separate region, which is administratively independent from the Walloon and the Flemish regions. The region is surrounded by the Dutch-speaking province of Vlaams Brabant.

There is no doubt that French is the dominant language in Brussels, both in terms of numbers of speakers and in terms of prestige. Since the Second World War, however, the Southern variety of standard Dutch, Belgian Dutch, has gained importance in the city (De Vriendt and Van de Craen 1990). This is due mainly to the industrial development of Flanders in the 1960s (Van Velthoven 1987), and the rising awareness in the city that 
bilingual skills are necessary for all higher public and private offices (De Vriendt and Willemyns 1987).

Before language legislation in combination with the economic developments mentioned above changed the status of Dutch in the city, French was the only prestige language in Brussels, as it was and is in Strasbourg. Learning French was therefore considered a prerequisite for upward social mobility. As a consequence, both cities have experienced language shift from the Germanic varieties to French, the details of which have been extensively documented especially for Brussels (Van Velthoven 1987; Louckx 1987; Witte 1987). Since Dutch has gained importance as a second official language in Brussels, the situation in the Belgian capital has changed. It is unclear whether Frenchification - as it is called by many Flemish authors - has slowed down or even stopped, and it may well continue to be an ongoing process among so-called Flemish immigrants in Brussels (Louckx 1987). It is clear, however, that the situation with respect to language shift differs from that in Strasbourg, where French is not in competition with another national language.

Another major difference between Brussels and Strasbourg has to do with the relationship between the language communities. Brussels was a major, if not the largest outstanding issue dividing the language communities in Belgium in the eighties (McRae 1986). A similar conflict is not reported for Strasbourg, however. The existence of a major ethnolinguistic conflict in Brussels has no doubt important consequences for language choice in everyday life, and, it is not unlikely that it has a bearing upon language contact as well, in that it creates an unfavourable climate for, for example, code-switching. Myers-Scotton (1990:6) assumes that code-switching as an unmarked choice does not occur when "the codes 
involved symbolize social groups in conflict/competition with each other." It must be kept in mind, however, that the high number of linguistically mixed marriages and the lack of residential segregation show that primary group contacts have always remained possible in Brussels (Louckx 1987).

\section{Historical aspects}

Both Brussels and Strasbourg have experienced different political and linguistic regimes in the course of history. Until 1648 Alsace belonged to the Germanic part of the Holy Roman Empire, but following the Thirty Years War, Alsace came under French rule. After the Franco-Prussian War, in 1870, Alsace returned to German rule, which lasted until 1918. From then onwards Alsace belonged to France, although it came temporarily under German rule again during the Second World War (Philipps 1975 and Gardner-Chloros 1991).

Brussels has experienced a similar change of political regimes in its past. In the 18th century the Southern part of the Netherlands was governed by the Austrian Habsburgs (17151794), after which it was taken over by France (1795-1814). From 1815 until 1830 the Southern provinces were part of the Kingdom of the Netherlands. After a revolution in 1830, the Southern provinces became the Kingdom of Belgium.

Each political change in Brussels and Strasbourg had its implications for language policy, which alternatively aimed to impose one or the other standard language on the population. The precise impact of those changes in language policy needs to be evaluated 
with care, because it often turned out to be difficult to implement the different policies. Thus, according to Philipps (1975, in Gardner-Chloros 1991) during the first period of French administration, between 1648 and 1789, German was the language of instruction in schools, because there were insufficient French teachers. Similarly, in the Southern provinces of the Netherlands the attempts at Dutchification by the Dutch king during the period of Dutch reign between 1814 and 1830 were unsuccessful (De Vriendt and Van de Craen 1990). Also, the efforts of the Brussels mayor at the end of the 19th century to provide instruction in Dutch for children from Dutch-speaking backgrounds met with strong opposition from both teachers and parents. In 1914 the so-called freedom of the head of the family was restored (Van Velthoven 1987).

\section{Educational aspects}

Although Brussels is a bilingual city, there are no bilingual schools (except the few international schools). Schools are either Dutch-speaking or French-speaking, although the other national language is taught to some degree in the French and the Dutch schools. According to De Vriendt and Willemyns (1990) only 15.3 percent of the overall number of pupils in Brussels are Dutch-speaking.

The situation in Alsace is very straightforward in that French is the sole medium of instruction. It is only since the Holderith reform in 1971 that German can be taught in the last two years of primary schools, but it is non-compulsory (Gardner-Chloros 1991). The code 
taught here is Standard German and not Alsatian. The are some occasional classes offered in "Langue et culture régionale", but these are not very popular according to Gardner-Chloros.

\section{Varieties used in the cities}

\section{Strasbourg}

The variety called Alsatian here belongs to the group of Low Alemannic dialects spoken in Alsace and Baden. It can be distinguished on a number of features from High Alemannic, spoken in the extreme South of Alsace and Baden, as well as from Rhine Franconian, which is spoken in the Palatinate and Lorraine (Philipp and Bothorel-Witz 1989). In Alsace, the Alemannic speech varieties co-exist with French. Standard German is present in a number of local newspapers and weekly papers, but is not used actively in everyday life (Tabouret-Keller 1985; Huck and Bothorel-Witz 1991; Vassberg 1993). According to Philipp and BothorelWitz it is only spoken with tourists and then rather badly. Because of the absence of Standard German in everyday life, Alsatian can be described in Kloss' (1977) terms as a "dachlose Außenmundart", which is often translated as "roofless dialect". Kloss (1977:224) defines roofless languages as "Sprachen für die zwar in anderen Ländern eine Standardform in 
Gebrauch ist, deren Sprecher aber in dem gerade untersuchten Lande diese Standardform

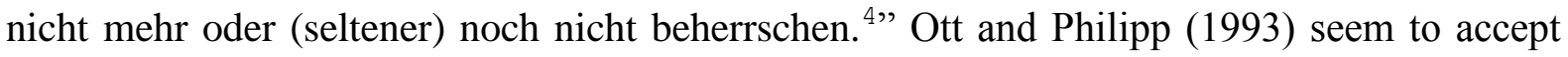
the idea of Alsatian as a roofless dialect, but point out that Alsatian developed without a "Dachsprache" and has survived throughout the ages despite the absence of such a "roof language”. Huck and Bothorel-Witz (1991), on the other hand, point out that Standard German functioned as the written code (Schriftsprache) in Alsace until the end of the First World War in 1918, when Alsace was returned to France. During the Second World War, German was imposed as a school language throughout the school system (Gardner-Chloros 1991), but the post-war generations grew up with French as the medium of instruction. As all observers agree that Standard German does not play a significant role in daily life in Alsace, it is probably correct to use the term "roofless dialect" for Alsace. The Alsatian situation also differs from the linguistic situation of German-speaking countries in that there is no regional colloquial variety of German (a German Regionale Umgangssprache) in Alsace (Hartweg 1983; Huck and Bothorel-Witz 1991; Ott and Philipp 1993).

Information concerning the numbers of speakers of Alsatian is available, but it is important to keep in mind that these figures relate to reported knowledge of the language, and speakers may underestimate or overestimate their proficiency in Alsatian. Most authors mention the INSEE ${ }^{5}$ survey that was carried out in Alsace in 1979 as an important source of information concerning numbers of speakers. This survey claims that $63.8 \%$ of the inhabitants of Strasbourg speak Alsatian and for Alsace as a whole the figure would be $74 \%$ (INSEE, in Hartweg 1985) ${ }^{6}$ Knowledge and use of Alsatian is going down, however. Bothorel-Witz and Huck (1996) point out that knowledge of Alsatian (connaissance 


\section{Jeanine Treffers-Daller}

déclarée) has gone down in Alsace by $15 \%$ between 1979 and 1992. Taking different opinion polls and surveys as their sources, Bothorel-Witz and Huck come to the conclusion that $60 \%$ of the inhabitants of Alsace knew Alsatian in 1992. The authors do not give separate figures for Strasbourg, but it is likely that the numbers of speakers of Alsatian have gone down in Strasbourg since 1979 as well. Hartweg (1983) shows that there are large differences between the reported language behaviour of respondents from Strasbourg and from the countryside in that respondents in the countryside claim to speak Alsatian significantly more often than those in Strasbourg (Hartweg 1983). The decline in knowledge of Alsatian is most noticeable in the younger age groups. Bothorel-Witz and Huck (1996) indicate that 34.5\% of the 14-17 year olds in Alsace still know the dialect and the percentage drops to $14.5 \%$ for the $6-11$ year olds. Detailed analyses of the knowledge and use of Alsatian among adolescents can be found in Cole (1975) and Veltman and Denis (1988), as discussed below under language attitudes.

Alsatian is used relatively little in the mass media (Tabouret-Keller \& Luckel 1981; Gardner-Chloros 1991). It is spoken in a number of regional television and radio programmes for a couple of hours per month (Hartweg 1983). German television and radio programmes from the neighbouring German-speaking states can easily be received, but they are mainly used for sport broadcasts or light music programmes for which, according to Hartweg, little competence in German is required. Hartweg points out that the Alsatian public mainly or exclusively chooses the French channels for news and political broadcasts. As far as the written media are concerned, there is little support for Alsatian. Hartweg shows that the number of copies of the bilingual editions of the Dernières Nouvelles d'Alsace went down from $63 \%$ of the total number of copies in 1965 to $30 \%$ of the total number of copies in 1980 . 
The number of monolingual French copies of the paper increased from $37 \%$ to $70 \%$ during the same period.

Finally, code-switching appears to be a widespread phenomenon in Alsace. Philipp and Bothorel-Witz point to the fact that "Alsatian never alternates with New High German, but always with French." According to Gardner-Chloros (1985: 166) the mixed discourse slowly takes over the symbolic function that Alsatian had in the past - the reinforcement of the regional identity and other aspects."

Hartweg (1985) gives a detailed overview of the domains in which French and Alsatian are being used and comes to the conclusion that there is no strict functional separation between French and Alsatian in everyday life anymore. Bothorel-Witz and Huck (1996: 45) come to the same conclusion and point out that "un raisonnement en termes de diglossie impliquant une délimitation précise des fonctions et des usages de la variété haute (français) et de la variété basse (dialectale) ne rend pas compte de la réalité alsacienne actuelle."

\section{Brussels}

The linguistic situation of Brussels is more complex than the language situation of Strasbourg, in terms of the number of different codes that are actually used in the city. According to De Vriendt and Willemyns (1987), three different varieties of Dutch, and three different varieties of French are found in the city, and this list does not take into account the 
varieties spoken by immigrants from Flanders and Wallonia. In addition to these indigenous varieties many immigrant languages are spoken in Brussels.

The inhabitants of Brussels speak local varieties of Dutch and French, from now on to be called Brussels Dutch and Brussels French, as well as supra-regional varieties, which are generally referred to as Belgian Dutch and Belgian French. Standard Dutch and Standard French are the official languages of Belgium and they are used in education, the media and also as spoken varieties by some groups. The Brussels Dutch dialect belongs to a group of Brabantic dialects spoken in the centre of Belgium. Although there is some variability in the dialects spoken in the capital, the different dialects "appear to display sufficient common characteristics that differentiate them from neighbouring dialects" (De Vriendt and Willemyns 1987: 204). It is not so easy, according to the same authors, to delimit Brussels French from Belgian French, as there is a continuum between speech that is heavily marked by characteristics of Brussels French to speech characterised by very few elements from Brussels French.

The codes mentioned above are used in different combinations by different groups of speakers, but the majority of the informants in my study spoke Brussels Dutch and Brussels (or Belgian) French. Knowledge of Belgian Dutch was relatively rare among the older indigenous informants.

It is hard to obtain any reliable figures concerning numbers of speakers of the different varieties, in part because questions on language knowledge and use no longer form part of the population censuses. According to the last official census containing information on the use of languages, there were 43.9 percent bilinguals in the city in 1947. More recent estimates of 
the number of speakers of Dutch vary from 14 percent, according to a survey in the French paper Le Soir in 1985, to 27 percent according to a survey made in 1967 for the Rassemblement pour le Droit et la Liberté. As the methodology and the questions asked differ each time, the results should be interpreted as indicating tendencies rather than exact figures.

With respect to knowledge and use of the dialects it is hard to obtain clear facts. According to the survey in Le Soir, 46 percent of the Belgian inhabitants of the city would have an active knowledge of "Bruxellois". It is not clear, however, whether this represents the Brussels Dutch or Brussels French. Willemyns (1984: 53 in De Vriendt and Willemyns 1987) reports that "Standard Dutch is used considerably more in Brussels and surroundings than in the remaining part of Flanders". According to De Vriendt and Goyvaerts (1989) hardly anyone speaks solely Brussels Flemish, and the number of active speakers of this variety is rather low.

Finally, with respect to code-switching, this phenomenon appears to be less widespread than in Strasbourg. In an earlier paper I have shown that code-switching is less frequent among informants who master the Southern variety of standard Dutch, Belgian Dutch and more frequent among speakers who know mainly Brussels Dutch and French (Treffers-Daller 1992). The combination of the rising importance of the standard language and the decline of the dialect were therefore assumed to explain the disappearance of codeswitching between Brussels-Dutch and French in Brussels.

It would be quite difficult to describe Brussels with the concepts of diglossia and bilingualism, because of the number of different codes involved and because different groups have their own language use patterns (see also De Vriendt and Willemyns 1987 for an 
overview of possible patterns). To some extent, the behaviour of the older indigenous inhabitants - a small minority, which is, now slowly disappearing - display a pattern of language use that can be described as bilingualism without diglossia. This group uses both Brussels Dutch and French for contacts in the daily neighbourhood, shopping and administrative contacts (Louckx 1978). Precisely because of the absence of a clear functional specialisation in language use, French-Dutch code-switching is found among this group rather than among other groups. The language behaviour of the older indigenous bilinguals is thus different from that of younger groups or immigrant groups from Flanders. Younger Brusselers reportedly tend not to not code-switch anymore. Treffers-Daller (1994) found a trend that younger informants switch less within sentences than older informants from Brussels. The younger Brusselers have an increasing knowledge of standard Dutch or its Belgian variety, and may use that code in formal contacts, but it is clear that they value bilingualism in view of their chances on the job market. The language behaviour of many groups in Brussels is probably more adequately described as "code alternation" (Thomason 1998). This term refers to the alternate use of two languages by the same speaker with different interlocutors. In the case of alternation, the two languages are rarely used in the same conversation, let alone in the same sentence. Instead each language has its own domain of use. The actual functional specialisation of languages remains largely unknown, however, for the majority of the groups in Brussels.

\section{Language attitudes}


Language attitudes are very complex in Alsace. Although Alsatian is valued as the symbol of regional identity, this overtly expressed favourable attitude is not always reflected in (reported) language choice patterns. Cole (1975)'s investigation into language use and language attitudes among 293 teenagers in Munster (Department of Haut-Rhin) shows that the teenagers as well as respondents from a broader population sample are convinced that it is important for an Alsatian to be able to speak Alsatian. At approximately fifteen years of age, however, the same teenagers choose to speak predominantly French with their parents. The preference for speaking French is even stronger in teenage peer groups. According to Cole (1975: 303) parents are inclined to accommodate their children in this instance rather than force them to speak predominantly Alsatian." Veltman and Denis (1988) confirm Cole's findings in their study of language use among approximately one thousand adolescents at fourteen different secondary schools in the departments of Haut-Rhin and Bas-Rhin. Even though $41.1 \%$ of the adolescents in this study can speak Alsatian, only $23.8 \%$ claim to use Alsatian frequently with their fathers and $21.2 \%$ with their mothers. Only $7.2 \%$ claim to speak it frequently with their friends, and girls speak Alsatian less frequently with their friends than boys. On the basis of these findings, Veltman and Denis conclude that young people have a negative attitude towards Alsatian and that usage is going down rapidly.

To my knowledge there are no comparable overviews of attitudes towards dialect or studies of (reported) dialect usage patterns in Brussels. Surveys that reveal language choice patterns are very difficult to carry out due to the tensions between the language groups. From the information that is available it is clear that Brussels Dutch does not play a role in public 
life, and that it is functioning in informal domains for a small group of speakers only. Standard Dutch has taken over the function of the dialect in Brussels, especially among the younger speakers. According to Willemyns $(1979,1984)$ Standard Dutch is used considerably more in Brussels than in the rest of Flanders. The emphasis on Standard Dutch is understandable if one realises that a non-standard variety of Dutch is no match for French with its international and cultural prestige. As a matter of fact, Francophones in Belgium have always claimed that there was no point in learning "Flemish" as it was only a cover term for a group of dialects. From the above it seems safe to conclude that there is a clear difference in attitudes towards dialect usage in Brussels and Strasbourg. Whereas Alsatian has overt prestige as the carrier of Alsatian identity and is still used by relatively large numbers of speakers, this is not the case for Brussels Dutch. In this context it may be important to point to the fact that according to McRae (1986), cultural diversity and linguistic pluralism are not seen as positive values in Belgium, in comparison to Switzerland. From the available literature it emerges that Alsatian/French bilingualism is more positively valued than Brussels-Dutch/French bilingualism.

\section{Summary}

The main differences between Brussels and Strasbourg have been summarised in the following table. It is clear that this table cannot be comprehensive. 
- insert Table 2 about here

\section{Lexical borrowing}

In this section we will try to show that the French influence on the Germanic varieties in Brussels and Strasbourg is limited to phenomena belonging to level 2, with maybe a few elements from level 3, in the borrowing scale presented by T\&K. It is clear that the contact situations discussed here go beyond a situation of casual contact (level one in the borrowing scale). At level 2, we find lexical borrowing, including function words such as conjunctions and various adverbial particles. Structural borrowing is restricted to minor phonological, syntactic and lexical semantic features. New phonemes with new phones may appear, but these will occur only in loan-words. Furthermore "syntactic features borrowed at this stage will probably be restricted to new functions (or functional restrictions) and new orderings that cause little or no typological disruption" (T\&K: 74).

A few words must be said about my use of the term "borrowing". In this paper an inclusive point of view is taken: the term "borrowing" refers to all insertions of single French words into Dutch or Alsatian utterances (or vice versa). The expression covers all kinds of single word elements: established borrowings, nonce borrowings (Sankoff, Poplack \& 
Vanniarajan 1990), as well as single word code-switches. Compounds are included in the counts but other frozen multi-word expression beyond the word-level, such as PPs are not. Proper names are excluded, because for the majority of these it is hardly possible to say to which language they belong. No claim is made as to whether an individual item is to be considered as an established borrowing, a nonce-borrowing or a code-switch. In TreffersDaller (1994) I have shown that 72 percent of the French single word items in the Brussels Dutch data can probably best be classified as established borrowings, as they can be found in dictionaries. The status of the remaining elements clearly needs further investigation, but this is beyond the scope of the present investigation. It is interesting to note here that the proportion of single word switches in the Alsatian corpus is approximately 26 percent of the total number of French single word items found in the Alsatian data (see below for more details). Thus, the amount of borrowing is approximately equal in both data sets: between 72 and 74 percent of all single word items are borrowings. As the borrowings outnumber the code-switches the term "borrowing" is chosen as the cover term for all elements. A further detailed quantification of the single word items, following the analysis of Poplack and Meechan (1995) may help establish whether an element ought to be classified as a borrowing or a code-switch. We do not consider this to be pertinent for the argument put forward in this paper, as the present discussion concentrates on the contrast between lexical versus structural mutual influences. All single word elements - whether code-switches or borrowings -classify as lexical rather than structural items, and therefore distinguishing borrowing from codeswitching is not crucial for the present purposes. 


\section{A quantitative perspective}

The Brussels and Strasbourg data show exactly the same asymmetry in that French words are easily borrowed in the Germanic varieties, whereas the lexical influence of the Germanic varieties on French is very limited. The Brussels Dutch parts of the data $(\mathrm{N}=156,660)$ contain 3988 French borrowings ( 2.55 percent), whereas the Brussels French parts of the transcripts $(\mathrm{N}=40,488)$ contain 118 Dutch borrowings (0.29\%). Gardner-Chloros (1991) quantified only single word switches and not borrowings in Alsatian and French. She found 117 French single word switches in Alsatian discourse and 25 Alsatian single word switches in French discourse (six recordings). In order to be able to compare the quantification of the patterns in the two corpora I counted single word switches as well as borrowings in Gardner-Chloros' data and found that the Alsatian parts of the transcripts $(\mathrm{N}=17,304)$ contained 452 French borrowings $(2.6 \%)$ whereas the French parts of the transcripts $(\mathrm{N}=6941)$ contain 39 Alsatian borrowings $(0.56 \%) .^{7}$ The quantitative patterns of the data are thus roughly the same, presenting an almost equal amount of borrowings in each corpus and a far larger proportion of borrowings from French than of borrowings from the Germanic varieties. Tables 3 and 4 give an overview of the borrowings in both corpora.

- insert Tables 3 and 4 about here - 
The overall picture that emerges from both tables is an asymmetrical one in that lexical borrowing is more frequent and also more diverse in the Germanic varieties than in the French varieties. In both cities, the main categories borrowed from French are nouns and interjections, followed by verbs and adverbs. Adjectives are borrowed relatively frequently in Brussels, whereas this is less frequent in Strasbourg.

In the opposite direction, borrowing is less diverse and the patterns are different. Interjections now form the largest group among the borrowings in Brussels and Strasbourg, followed by nouns. In the Brussels data set conjunctions are also borrowed relatively frequently.

\section{A qualitative perspective}

\section{Conjunctions, adverbial particles and prepositions}

$\mathrm{T} \& \mathrm{~K}$ consider borrowing of some function words, more specifically conjunctions and adverbial particles, to be typical for level two in their borrowing scale. In Brussels Dutch one finds, as a matter of fact, some borrowed subordinate conjunctions: tandis que (while) et malgré dat (from French malgré que - in spite of the fact that) and à moins dat (from French

à moins que - unless). It is difficult to distinguish Dutch and French co-ordinating conjunctions in spoken language, as they are relatively similar (Fr. et - Br.D. en / Fr. mais [m\$3]- Br.D. mo [m\$2]). In the Strasbourg data there are two occurrences of the French 
subordinate conjunction parce que (because), and one occurrence of mais (but) in Alsatian discourse.

The list of adverbial particles borrowed in Brussels Dutch seems to be slightly longer than in Alsatian, but this may be due to the differences in corpus size. Among the particles found in both cities we may quote à peu près (approximately), d'ailleurs (besides), au fond (basically) and donc (so). These elements can function as adverbs as well as conjunctions and discourse markers, and it is not possible to go into these differences here. A detailed analysis of the distribution of these elements in Brussels Dutch discourse is given in Treffers-Daller (1994).

In addition to the elements mentioned above, the Brussels Dutch corpus contains five sentences in which French par (by, per) is borrowed into Brussels Dutch, cf. (1).

$\begin{array}{llllllll}\text { (1) } & \text { kunnenwe } & \text { nog } & \text { just enen dag } & \text { par } & \text { week } \\ \text { Now can we } & \text { still just one day per } & \text { week }\end{array}$

"Now we can only go once a week." (Treffers-Daller 1994: 114)

If it is correct to consider par as a preposition, this would be evidence that lexical borrowing goes beyond level 2 in Brussels. Possibly this preposition is the only one borrowed into Dutch because it is almost homophonous with the Dutch preposition per. The use of French par corresponds to Dutch per in three out of five cases, as in (1) above. In the two other cases, French par occurs in the expressions "een par een" (one by one) and "negentig par honderd" (ninety out of hundred). In these two expressions similarity between French par and Dutch 
per cannot explain the occurrence of the French preposition, as the Dutch equivalent in these cases is not per but voor (for, by) in the expression een voor een (one by one) and op (on) in negentig op de honderd (ninety out of a hundred). ${ }^{8}$ In the majority of the switches or borrowings containing prepositions, the prepositions occur in more or less fixed combinations of a preposition and its complement, as in the expressions par coeur (by heart) and par voiture (by car). The Alsatian corpus contains two occurrences of the compound preposition vis-à-vis ${ }^{9}$ (opposite, across). In French vis-à-vis would normally occur with the preposition de (of). In the Strasbourg data set, vis-à-vis occurs in combination with the German von (of), thus forming a bilingual compound preposition, as in (2).

(2) 'S isch dort vis-à-vis von derre Wirtschaft

It is there opposite of that café

"It is there opposite that café." (corpus Gardner-Chloros, conversation $\quad$ E:p12)

It is clear, however, that prepositions are hardly ever borrowed in isolation in either data set.

\section{Basic and non-basic vocabulary}

The lexical items borrowed into Brussels Dutch do not belong to the basic vocabulary. Although some isolated examples were found of a borrowed impersonal pronoun or a cardinal number, these represent individual, isolated examples, not typical for Brussels Dutch. The data available for Alsatian seem to confirm this analysis for Strasbourg. Matzen (1985) gives 
an overview of French borrowings in Alsatian but does not provide examples of borrowings belonging to the basic vocabulary of Alsatian.

\section{Derivational morphology}

Brussels Dutch has borrowed a number of derivational morphemes, most of which have been morphonologically adapted to Brussels Dutch. The following are just a few examples of morphemes borrowed into Brussels Dutch:

-us\$4 (Fr. -ation) in [realizus\$4] (realisation), -itajt (Fr. -ité) in [raritajt] rarité, (rarity), -ant as in [fatif2ant] (tiring) and -ub\$41 as in [r\$3:z\$2ub\$41] (reasonable). There are many forms containing borrowed suffixes, and some of these occur also without the suffixes mentioned above, as we can see in realiseren (to realise) or rare (seldom), raison (reason), fatigue (tiredness). The fact that the roots can occur without the derivational suffixes, or in combination with other derivational suffixes, is an indication that the roots and the suffixes are borrowed independently from each other. In other cases, however, the suffixes seem to form a unity with the roots, and cannot be separated, as for example in the case of portabel (portable). In those cases the roots and the suffixes probably form unanalysed units. 
It is not possible to attach these suffixes to Germanic roots, as we can see in the following examples: *zeker-iteit (Du: zeker-heid, Eng: certainty or *drink-abel (Du: drinkbaar, Eng: potable). This is an indication that borrowing in Brussels Dutch is limited to level 2 on T\&K's borrowing scale. On the contrary, Dutch suffixes can be attached to French adjectives, as we can see in e.g. koleir-ig (quick-tempered), where the Dutch suffix -ig is attached to French colère (anger).

In Brussels Dutch verbs are integrated with the help of the morpheme -er, which is also borrowed from French. In total 800 verbs are integrated through this routine. These tokens represent 123 different types. In Alsatian, the morpheme -ier serves the same purposes. The morpheme -er/-ier is attached to the roots of borrowed verbs, which are then conjugated according to Brussels Dutch or Alsatian rules. Matzen (1985) points out that many French verbs have entered the Alsatian dialect through the intermediary of German, as German was already considerably influenced by French in the eighteenth and nineteenth centuries. Examples of such indirect borrowings are isoliere (to isolate), maschiere (to march) and abonniere (to subscribe). Other verbs, such as ambetiere (to annoy), exküsiere (to excuse) and schwassiere (to choose) are directly imported into Alsatian from French.

There is an interesting difference between the rules for the formation of the past participle forms of these verbs in Dutch and Alsatian. The prefix ge-, which is attached to all roots from French in Brussels Dutch, does not appear on the same verbs when they are borrowed into Alsatian. Thus, the past participle form of arrangeren/arrangieren (to arrange) differs in Brussels Dutch and Alsatian: 
(3a) ge-arrang-eer-d (Brussels Dutch)

PastPart-arrange-ER-PastPart

"arranged"

(3b) arrang-ier-t (Alsatian)

arrange-IR-PastPart

"arranged"

These differences are discussed in detail in Treffers-Daller (1997 and in press). For the present purposes it is only important to see that the suffix -er cannot be attached to Germanic roots. Thus, in Dutch (4b) is excluded, because -er has been attached to the English root bridge. ${ }^{10}$

(4a) bridg-en

bridge-INF

"to play bridge"

(4b) *bridg-er-en

bridge-er-INF

"to play bridge"

It is clear that -er is borrowed separately from the verb root as it can be attached to verbs which do not belong to the -er paradigm in French but to the -ir class or the -re class. Thus 
French offrir (to offer) becomes offr-er-en and finir (to finish) is borrowed as finiss-er-en. There are a few examples of verbs belonging to the -re class in French which are borrowed with the help of the -er suffix: thus, traduire (to translate) becomes either traduct-er-en or traduis-er-en. In one case the stem of the noun traduction (translation) is used as the basis for the integration of the verb and in the other case the verb stem traduis. Matzen's (1985) examples of verbs that are imported indirectly into Alsatian through the intermediary of

German all belong to the -er class in French. Among the examples Matzen gives of verbs directly borrowed from French in Alsatian, however, there are not only verbs belonging to the class in -er, but also a number of verbs belonging to the verb class in -ir, such as mainteniere (to maintain) and schwassiere (to choose). Matzen also shows that French verbs that are borrowed in Alsatian often obtain primary stress on the first or the second syllable, rather than on the last syllable. To my knowledge a detailed study of this phenomenon has not yet been made for Alsatian. In Brussels Dutch primary stress is on the syllable containing -er.

\section{The gender of borrowed nouns}

French nouns generally keep their gender when borrowed into Brussels Dutch. Thus, musée (museum) and numéro (number) are masculine, whereas allumette (match) and bougie (candle) are feminine. Only few borrowings are classified as neuter (see Treffers-Daller 1994 for a detailed analysis). To our knowledge, a detailed analysis of this phenomenon has not yet been made for Alsatian. 


\section{Lexical borrowing: conclusion}

Lexical borrowing is extensive in Brussels Dutch and in Alsatian, but it remains limited to non-basic vocabulary, and the derivational suffixes borrowed into the Germanic varieties can only be combined with French roots. The evidence presented so far makes it likely that lexical borrowing in the Germanic varieties is limited to level 2 in T\&K's borrowing scale.

\section{Loan shifts and loan blends}

Influence in the lexicon can also be observed in the form of literal translations of expressions. Haugen (1950) coined the term loan shifts for this phenomenon. Other authors prefer the term calques. In the case of loan shifts, "only a meaning, simple or composite is imported, but the forms representing this meaning are native" (Appel and Muysken 1987: 165). This type of interlingual influence is well-known from the work of prescriptivists in the different areas, but many descriptive linguists have also included lists of loan shifts in their work. T\&K do not discuss this type of interlingual influence in their work, even though I think it is another important characteristic of interference through shift. Thomason (p.c.) points out that calques are perhaps closer to structural than to lexical borrowing and therefore I treat them here separately from lexical influence. 
Part of the so-called alsacianismes (Wolf 1983) appear in Belgium under the name belgicismes (Hanse, Doppagne \& Bourgeois-Gielen 1974 et seq). But the lists do not only contain words or expressions that can be traced back to the Germanic varieties: they also contain archaisms and administrative terms that are typical for Belgium and Alsace. The term gallicismes is used for expressions translated from French into the respective Germanic varieties. Gardner-Chloros (1991: 177) gives the following example for Strasbourg: Achtung mache (attention make) from faire attention (to pay attention). The same expression occurs in the Brussels Dutch corpus: attentie doen (attention make). ${ }^{11}$ As is evident from these examples, loan shifts do not only involve individual words, but also the substitution of idiomatic expressions or collocations. It is very difficult, if not impossible to quantify these. Many of them may remain unnoticed as they often involve the importation of meaning only: morphemes are not imported in many cases. Still I think it is possible to make the following generalisation: whereas lexical influence in the form of loan words is very important in the Germanic varieties, it is not in the French varieties. Lexical influence in the form of loan shifts, on the other hand, is more important in the French varieties than in the Germanic varieties.

The Brussels data set also contains a limited loan blends or hybrid forms, that is compounds which consist of a French a Dutch part. They occur in four types, as can be seen in table 5.

In the mixed compounds of type 1 , the heads are Dutch, whereas in type 2 , the heads are French. In type 3 the two roots are of French origin, but the syntactic structure and the stress pattern is Dutch, just as in the two preceding types ${ }^{12}$ : all of the compounds in type 1 
through 3 are head-final and primary stress is on the first half of the compound. In type 4, on the other hand, the syntactic structure and the stress pattern of the compounds are French. Both compounds of type 4 are head-initial and stress is on the second half of the compound. I still consider type 4 as a mixed compound, and not as a completely French form, because the forms can take and -s plural which is probably a Dutch inflection (see below). The plural -s of journal parlés and of sens uniques is audible, which would not be the case if the plural were French. Thus, these forms are to a certain extent morphologically integrated, although this is only visible in the plural form. Type 1 through 3 is clearly more integrated than type 4 from a syntactic and a phonological point of view.

The Strasbourg corpus contains one hybrid compound: auto-Brill (car glasses) ${ }^{13}$, which consists of a Germanic head preceded by a French adjunct, thus conforming to the hybrid compound type 1 distinguished above. More interesting perhaps is the French compound Agnès produces in conversation B: moutarde sauce (mustard sauce). This compound is head-final, even though it consists of French components only and thus appears to be similar to pattern 3 described above. ${ }^{14}$ In Alsatian newspapers and other written sources one can find mixed compounds belonging to the different categories distinguished above. Hartweg (1985: 1970) gives a.o. the following examples: Adjoint-posten (position of alderman), Polizei-permanence (policestation) and Coiffeur-meister (hairdresser-master) ${ }^{15}$.

- insert Table 5 about here - 
Jeanine Treffers-Daller

\section{Mutual structural influences}

In this section the focus is on phonological, syntactic and morphological interference in the French and the Germanic varieties spoken in Brussels and Strasbourg. Due to lack of space, this overview cannot be complete, but it intends to provide a clear picture of the asymmetries between the mutual influences.

\section{Phonological influences}

\section{The Germanic varieties}

The phonological influence of French on Brussels Dutch is relatively limited in that phonemes from French appear in borrowings from French only and not in native vocabulary. In their list of Brussels Dutch phonemes, De Vriendt and Goyvaerts (1989) do not mention the adoption of any French phonemes into Brussels Dutch. In many cases, French phonemes are adapted to the Brussels Dutch phonological system, as in the case of the nasal vowel in adjectives ending in -ent/ant ${ }^{16}$. Thus French embetant [\$9b\$3t\$9] becomes ambetant [amb\$4tant] in Brussels Dutch. ${ }^{17}$ Other borrowings from French keep the French nasal vowels $/ \$ 6 /, / \$ 7 /, / \$ 8 /$ and $/ \$ 9 /$ as in sympatiek (sympathetic) [s $\$ 8$ patik], donc (so) [d $\$ 6 \mathrm{k}$ ] 
and emprunt (loan) [\$9pr\$7 $]^{18}$. In Brussels Dutch nasality is not a distinctive feature in vowels, although vowels may become nasalised in some contexts (see De Vriendt and Goyvaerts 1989). With respect to the consonant system, French phonemes again appear only in borrowings from French, as we can see e.g. in the occurrence of the voiced velar plosive /g/ in degoutant (disgusting) and the voiced palatal fricative $/ £ 4 /$, in courage (courage) [k\$2r\$2£4\$4] and gentil (kind) [£4anti]. De Vriendt (p.c.) doubts whether $\{4 /$ is a phoneme of Brussels Dutch, as there are no minimal pairs, which show its phonemic status. But the voiced palatal fricative does occur in native vocabulary, as we can see in zwoerd (rind) [£4w\$2£4\$4], zabberen [£4ab\$4r\$4] (Du: morsen, Eng: to spill), kajoebereer [ka£4ub\$4r\$3:r] (Du: landloper, Eng: tramp). In some older loan words, [£4 occurs but its occurrence is the result of phonetic adaptation processes. As the voiced palatal fricative is not present in the French origin, [£4] is not adopted from French in [ $\$ 2 \mathrm{k} \$ 2 £ 4 \$ 4$ (occasion). The French pronunciation of occasion is [ $\$ 2 \mathrm{kazj} \$ 6]$.

In their description of the phonemes of Low Alemannic, Philipp and Bothorel-Witz (1989) do not mention any borrowing of French phonemes. As it is clear from GardnerChloros (1991) that many loan words from French retain their original pronunciation when borrowed into Alsatian, it is assumed that the situation in Alsatian is similar to the situation sketched for Brussels Dutch, in that French phonemes occur only in French loan words and do not occur in native vocabulary. According to Bickel-Kaufmann (1983, in Gardner-Chloros 1991) there is a clear influence of French phonology in Alsatian as spoken by (male) adolescents in Andolsheim, but French influence was not found in the speech of older 
Alsatian speakers. A definitive conclusion about the influence of French phonology on the Germanic varieties can not yet be drawn however on the basis of the available information.

\section{The French varieties}

The influence of Brussels Dutch on French as spoken in Brussels appears to have been very important. Baetens Beardsmore (1971) mentions among other things the devoicing of voiced stops and fricatives in final position (see also Piron 1979), as in flamande [flamant] (Flemish) or belge (Belgian) [bel£5], which is one of the most typical characteristics of Brussels French. It is interesting that the voiced velar consonant $/ \mathrm{g} /$ is often replaced by a voiceless velar fricative in final position, as in fatigue (tiredness) [fati£1]. A Brussels French tendency towards diphthongisation, as in coucher (sleep) [ku£5ej] or heureux (happy) [ $\$ 5 \mathrm{r} \$ 5 \mathrm{j}]$ is also attributed to a Dutch substrate. Finally the fact that the main accent is frequently moved towards the front of a word is attributed to influence of Dutch, as in 'reposant (restful). This phenomenon is also supposed to be characteristic of French as spoken in Malmédy and Arlon, which has been influenced by a German substrate (Boileau 1946, in Baetens Beardsmore 1971). Philipp and Bothorel-Witz (1989) report the same shift in stress towards the first syllable for Alsatian French, where 'mademoiselle (miss) is apparently pronounced with primary stress on the first syllable.

As far as the influence of Alsatian on French as spoken in Alsace is concerned, Weinreich (1953) already mentions the existence of phonological interference. Weinreich 
shows that the phonological system of the German variety is maintained in the pronunciation of sounds in Alsatian French. Voiced and voiceless consonants are not different phonemes but allophones, as is also the case in the Germanic variety. Between two vowels consonants are voiced, but they are unvoiced in all other contexts. Thus, bette (Chinese cabbage) is pronounced as [p\$3t] and épée (sword) as [ebe] (see also Philipp 1985). Philipp (1964, 1967 and 1985) makes a detailed analysis of phonological interference in French as spoken by inhabitants of Blaesheim, a village close to Strasbourg. She shows that transfer of phonological features from the Germanic dialect in French is extensive. Transfer is not only visible in the distribution of voiced and unvoiced consonants, but also in the vowel system and in the stress patterns on words and phrases. The dialect of Blaesheim differs from the dialect of Strasbourg, however, despite the fact that Blaesheim is situated at fifteen kilometres from Strasbourg (Philipp 1967). The patterns of phonological interference in Strasbourg and Blaesheim may therefore be different as well. Still, the results described for Blaesheim provide a clear example of phonological interference in French as spoken in Alsace. The facts that have been discussed here seem to indicate that phonological interference in the opposite direction (from French in the Germanic varieties spoken in Alsace) is far less extensive.

\section{Morphological influences}

\section{The Germanic varieties}


According to Taeldeman (1977), the influence of French on the varieties of Dutch spoken in Belgium is less important in morphology than in phonology. There are only a few examples in which the inflectional morphology of local Dutch varieties seems to have been influenced by French, as in (5), where the plural form meters is used in a construction after a cardinal number. In standard Dutch no plural ending is heard here.

$\begin{array}{lcccccc}\text { een } & \text { schilderij } & \text { van } & 2 & \text { meters bij } & 70 & \mathrm{~cm} \\ \text { a } & \text { painting } & \text { of } & 2 & \text { metres by } & 70 & \mathrm{~cm}\end{array}$

De Vriendt (p.c.) points out that the plural forms of meter and kilo exist in Dutch, after quantifiers, such as enkele (some, a few) but not after cardinal numbers. Thus, in standard Dutch the plural -s occurs in enkele meters (a few meters) but not in twee meter (two meters). Apparently the plural form is used in more contexts in the Southern Dutch dialects than in standard Dutch, but the systems of the different Dutch varieties are relatively similar. French influence is not very likely in this case, because plural endings cannot be heard in French on words like mètres or litres, and dialect speakers were most probably influenced by spoken French rather than by written French.

French borrowings can obtain either an -s or a schwa in the plural form. Both these plural forms occur on native nouns as well. In the majority of the cases, the borrowings are inflected with the $-\mathrm{s}$ plural suffix $(\mathrm{N}=85)$, as in the case of camions (lorries) and facteurs 
(postmen). In these examples the plural -s is pronounced, as is normal in Brussels Dutch (tafel - tafels (table)). The second largest group of French borrowings obtains a schwa in plural (N $=40$ ), as in pressen (presses) and collen (collars). Some nouns have a variable plural suffix, such as commiesen (shopping), which is also found as commieses.

It is clear that the schwa plural is Dutch, but one may wonder whether the -s plural is Dutch or French. There are different arguments for considering this -s as Dutch rather than French. In the first place, because it is pronounced, which is normal in Dutch but not in French. In the second place, there are nineteen examples of French borrowings that obtain a Dutch diminutive and an $-\mathrm{s}$ plural, as in (6). These borrowings have thus been morphologically integrated into Brussels Dutch, it is likely that the plural morpheme -s which follows this diminutive is Dutch too.

(6)
...met die manch-ke-s in zilver en alles
...with the handle-DIM-s in silver and everything

"With the little handles in silver and everything." (corpus JTD, tape 36, Gust, p 17)

The fixed expression journal parlés (news bulletin) in (7) gives additional evidence for the fact that the -s is Dutch rather than French.

$\begin{array}{lllll}\text { Hij beziet } & \text { on al de journal parlés. } \\ \mathrm{He} \text { watches } & \text { on all the news } & \text { spoken }\end{array}$

"He watches all the news bulletins." (Treffers-Daller 1994:163) 
The noun journal is singular, but the following adjective parlés (spoken) is plural. As in the cases cited above, the -s in pronounced. If the form is considered as a French compound, it is difficult to explain the plural on the adjective, occurring in combination with a singular noun. ${ }^{19}$ In French, the noun would take the plural form journaux (journals) and the compound would be pronounced as follows: journaux parlés [£4urno parle]. If the -s is considered as a Dutch -s, the absence of a plural marker on the noun can easily be explained. In Dutch compounds are pluralised by attaching a suffix to the head noun, not by attaching it to the adjunct. Thus, compounds obtain only one plural suffix, to their utmost right, as we can see in velowinkel (bicycle shop), which is pluralised as follows: velowinkels. An -s cannot be attached to velo in this compound.

There is one example in which the plural marking on the adjective cannot be interpreted as Dutch, because in Dutch there is no $-\mathrm{s}$ inflection on adjectives. This $-\mathrm{s}$ is probably best interpreted as a French -s. This example is an exception in the data, however.

$\begin{array}{lll}\text {...want } & \text { ze hebben, euh, draconiens [drakonj\$8s] } \\ \text {...because they have, } & \text { ehm, radical }\end{array}$

$$
\begin{array}{ll}
\text { middelen } & \text { gepakt } \\
\text { measures } & \text { taken }
\end{array}
$$

"Because they have taken, ehm, radical measures." (Treffers-Daller 1994:162) 
Taeldeman (1977) also suggests that the occurrence of analytical comparatives in the Southern Dutch dialects can be explained on the basis of French analytical comparatives. Thus, one finds meer gevarieerd < plus varié (more varied) instead of the synthetic comparative gevarieerd-er as is regular in Dutch with gradable adjectives. My Brussels Dutch corpus contains some analytical comparative forms. The adjectives sectaire (sectarian) in (9) and administratief (administrative) in (11) are not likely to obtain a synthetic comparative anyway, as they are not gradable in most cases. ${ }^{20}$ It is therefore questionable whether French influence needs to be invoked to explain these forms.

(9) D' ouwe met da's meer sectaire (corpus JTD, Gust 7:24) The old market, that's more sectarian

"On the old market, there is a more sectarian (atmosphere)."

(10) Maar op Molenbeek, dat is, daar hoort ge 't al, But on Molenbeek, that is, there hear you it already,

$\begin{array}{lll}\text { dat is } & \text { meer } & \text { Vlaams } \\ \text { that is already } & \text { more Flemish (corpus JTD, Gust, 7: 24) }\end{array}$

"But in Molenbeek, that is, there you hear it already, that is more Flemish already." 
(11) $\mathrm{Da} \quad \mathrm{s}$ allemaal meer administratief (corpus JTD, Oscar, 2: 12)

That 's all more administrative

"All that is more administrative."

As we can see in (12a) and (12b) it is possible to attach Dutch comparative and superlative endings to gradable adjectives borrowed from French, as with plezant (from French plaisant; Eng attractive, pleasant).

(12a) plezant-er (corpus JTD, tape 69, Claire, p. 12)

more pleasant

(12b) plezant-st

most pleasant

Adjective inflection is Dutch, on native vocabulary as well as on borrowed vocabulary, as we can see in (13) where the schwa on sympathique is a Dutch ending required on adjectives in a headless NP (that is, a noun phrase without a head noun).

(13) Da's ne sympathique [s\$8patik] (Treffers-Daller 1994: 152) 
That's a sympathetic

"That's a sympathetic one."

De Vriendt (p.c.) points out that gentil (kind) is slightly different from the cases sketched above, in that it is pronounced with a short vowel when used in combination with a masculine noun as in ne gentil jongen [n\$4 $£ 4$ anti ju£3\$4] (a kind boy), whereas a long vowel occurs when the adjective is followed by a feminine noun as in een gentille vrouw [ $\$ 4 \mathrm{n} £ 4$ anti: vra] (a kind woman). This pronunciation can be heard in many parts of French-speaking Belgium. It is clear that the adjective is not adapted morphonologically to Dutch, but is still inflected according to (Belgian) French rules.

Brussels Dutch does not borrow any verbal inflections from French. We have already seen that French verbs are integrated with the help of a derivational morpheme, onto which Dutch inflection is added.

In the literature no information is available about Alsatian inflectional suffixes on borrowed French lexical items.

\section{The French varieties}

According to Piron (1979:207) the morpho-syntax of French as spoken in Belgium has hardly been influenced by Dutch dialects. Baetens Beardsmore and Piron both point to the fact that 
many of the characteristics of Brussels French can also be found in varieties of French spoken in the North of France. Thus, morphological influence from Dutch need not been invoked to explain the characteristics of Brussels French morpho-syntax. Among the facts which could be due to influence from Dutch, Baetens Beardsmore (1971) mentions the absence of subjunctive verb forms, which are replaced by forms of the indicative. Furthermore, adjectives tend to be invariable, especially in predicative position. As predicative adjectives are invariable in Dutch, this may be seen as influence of the Dutch dialects. There are some examples of this phenomenon in my data. In (14) the French adjective furieux (furious) ends in a diphthong $[\$ 5 \mathrm{j}]$ and not in a $-\mathrm{z}$, as would have been the case if there had been agreement between the subject and the adjective.

(14) Celle-ci elle est furieux hein (corpus JTD, Léontine tape 5:13)
This one, she is furious he
"This one is furious."

Similarly, for Alsatian French, lack of agreement between adjectives and nouns is attributed to influence from the Germanic varieties (Wolf 1983).

(15) La maison est blanc (Wolf 1983: 190)
The house
is white

"The house is white." 
Syntactic influences

\section{The Germanic varieties}

The word order of the main clause and the subordinate clause in Brussels Dutch has hardly been influenced by French syntax, as shown in Treffers-Daller (1994). I only found that Brussels French adverbs, when borrowed in Dutch, appear in a pre-clausal position instead of in the first position in the sentence, cf. (16).

$\begin{array}{llllll}\text { D'ailleurs 't } & \text { gasthuis } & \text { heeft } & \text { ook } & \text { geconfirmeerd } \\ \text { By the way the hospital } & \text { has it } & \text { also confirmed }\end{array}$

"By the way, the hospital has confirmed it too." (Treffers-Daller 1994: 175)

Thus, the position of adverbs borrowed from French differs from the position of native adverbs, which can and generally do occupy the position directly preceding the finite verb, cf. (17).

(17) Dan heeft 't gasthuis 't ook geconfirmeerd

Then has the hospital it also confirmed

"Then the hospital has confirmed it too." 
There is no evidence for the emergence of a VO structure in Brussels Dutch or for the loss of Verb Second, as has been reported for Australian Dutch by Clyne (1987). In Brussels Dutch, objects appear to the left of the main verb in main clauses, cf. (18), where een brief (a letter) is to the left of gemaakt (made).

Surtoutze hebben een brief gemaakt.
Above all, they have a letter made
"Above all, they have made a letter." (Treffers-Daller 1994:192)

Word order in the subordinate clause remains unchanged, even in sentences containing borrowed subordinate conjunctions, as in (19). The inflected verb hebt (has) appears at the end of the subordinate clause, as in normal in Dutch.

$\begin{array}{lllll}\text { A moins dat } & \text { ge } & \text { 'm dar onder de dictionnaire gezet hebt } \\ \text { Unless } & \text { you } & \text { it there under the dictionary put has }\end{array}$
"Unless you have put it under the dictionary." (Treffers-Daller 1994: 191)

In Alsatian there is no evidence for major changes in word order in the main clause or the subordinate clause either, as can be seen in (20) and (21). In (20) the inflected verb het (has) occupies the second position after the preposed adverbial constituent drej Woche lang (for 
three weeks). In (21) the finite verb muess (must) appears in the final position in the subordinate clause, as is regular in German.

Drej Woche lang het er 's versproche... three weeks long has he it promised "He promised it for three weeks." (Gardner-Chloros 1991: 138).

(21) Sogar wenn er üwwer Middaa noch emol Even if he over afternoon more once hole $\quad$ muess (Gardner-Chloros 1991: 151) get must

"Even if he has to go get some more in the afternoon."

The syntactic influence of French on Brussels Dutch is limited to some peripheral phenomena, such the frequent use of the preposition van (of) in constructions that appear to be literal translations from French constructions containing the preposition de (of), which introduces either a prepositional phrase, as in (22), or an infinitival complement, as in (23). In 
Standard Dutch, the preposition over (about) is used in (22) and the complementiser om (to) appears in infinitival constructions like $(23){ }^{21}$

(22) Ik spreek van de joueurshe (corpus JTD, 1:1)

Je parle de les joueurshe (de+ les contracts to des in French)

I speak of the players you know

"I speak about the players."

$(23)$

$\begin{array}{lllll}\text { Totdat meneer } & X & \text { 't } & \text { goed gedacht } & \text { heeft } \\ \text { Until mister } & X & \text { the } & \text { good idea } & \text { has }\end{array}$

van in de vuilmannen te bezien.

to in the dustbins to look

"Until Mr X had the good idea to have a look in the dustbin." (corpus JTD, tape 6,Mariette: 4)

This phenomenon is not restricted to Brussels only, but occurs in other Southern varieties of Dutch, including the Southern Dutch Standard variety, Belgian Dutch (cf. De Clerck 1981). It is, as a matter of fact, one of the well-known so-called gallicisms of Belgian Dutch. The use 
of van is interesting, because it is sign of syntactic change, which is relatively widespread and occurs in sentences, which may consist of native (Dutch) vocabulary only. Thus, contrary to the situation described above for the integration of French adverbs, Brussels Dutch has not borrowed any lexical material here. Instead the syntactic functions of a native element are extended, probably under the influence of similar French structures.

\section{The French varieties}

De Vriendt (1988) gives a detailed analysis of Dutch influence in Brussels French syntax. Among the facts discussed is the fronting of direct objects, as in (24):

$\begin{array}{llll}\text { Dix } & \text { francs moi } & \text { je } & \text { donne (De Vriendt 1988: 69) } \\ \text { Ten francs me } & \text { I } & \text { give }\end{array}$

It is important to note that the direct object dix francs is not repeated in the main clause by a pronoun, which makes this construction different from double markings found more generally in standard spoken French (Blanche-Benveniste, Bilger, Rouget \& Van den Eynde 1990), see (25) and (26): 
$(25)$

Ça, je le trouve pas beau (Hawkins 1993: 56)

That, I it find not beautiful

"I don't find it beautiful."

Moi le poste je $l^{\prime}$ écoute jamais

I the radio station $I$ it listen never

"I never listen to the radio station." (Blanche-Benveniste 1990:87)

In Brussels French, many different constituents can occupy the first position in the sentence, even though in the majority of the examples it is ça (that) is fronted. In the Alsatian corpus, however, there are very few examples of constituents placed in front of the subjects. In the two examples found, ça (that) occupies the first position, see (27).

$\begin{array}{llll}\text { Ça, } & \text { elle } & \text { sait } & \text { faire } \\ \text { That, } & \text { she } & \text { knows } & \text { do }\end{array}$

"She can do that." (corpus Gardner-Chloros: Marie, conversation B: p18)

Example (28) is taken from an invented dialogue at the end of a prescriptivist grammar of Alsatian French. This example is meant to show that full NPs can be placed in the first position of the sentence before the subject in Alsatian French, and not only ça. Wolf (1983) does not mention this construction for Alsatian French, however. 


(28) Ça, la viande rouge j' aime le plus
That, the meat $\quad$ red $\quad$ I love the most
"That, red meat I love most." (Cron 1902 in Gardner-Chloros 1991: 196)

According to De Vriendt, the influence of Dutch in the fronting of constituents is possible or even certain, but the author also points to the fact that the phenomenon has not been sufficiently described for modern French to make a definitive conclusion possible.

Wolf (1983) and De Vriendt (1988) both report that direct objects may follow indirect objects in the French spoken in Strasbourg and Brussels respectively, cf. (29) and (30). Both authors assume that the existence of parallel structures in the Germanic variety can be invoked to explain these structures.

$\begin{array}{cccccc}\text { (29) Je cherche } & \text { à } & \text { mon frère } & \text { une } & \text { gomme } \\ \text { I } & \text { search } & \text { for my brother } & \text { an eraser }\end{array}$

"I am looking for an eraser for my brother." (Stoeckle 1974 in Wolf 1983:194)

(30) Et j' ai jamais demandé à quelqu'un quelque chose and I have never asked to somebody some thing "And I have never asked anybody anything." (De Vriendt 1988: 75) 
It needs to be investigated how frequent this phenomenon is in actual spoken Alsatian French and Brussels French, as the corpora under investigation here do not contain constructions of this type.

Wolf also gives examples of the occurrence of a direct object between auxiliaries and past participles, as in (31). This phenomenon, which Wolf attributes to influence from German, does not appear in the corpus of spoken Alsatian French, however. The phenomenon is not attested for Brussels French either.

\begin{tabular}{|c|c|c|c|c|}
\hline (31) $\quad \mathrm{J}^{\prime}$ & ai & le & travail & fini (Stoeckle 1974, in Wolf 1983: 194) \\
\hline I & have & the & work & finished \\
\hline
\end{tabular}

"I have finished the work."

In both the Brussels and the Strasbourg corpus one finds examples of sentences containing modal particles, such as une fois (some time) in different constructions which correspond to German and Dutch usage, according to Wolf (1983), Baetens Beardsmore (1971) and De Vriendt (1988), see (32) and (33).

$\begin{array}{ll}\text { (32) } & \text { une fois voir } \\ \text { Come } & \text { one time see }\end{array}$

"Come and have a look some time." (corpus JTD: Léontine tape 5: 1) 
(33) Faudrait une fois le faire

ought to one time it do

"You ought to do it some time."

(corpus Gardner-Chloros: Annie, conversation B, page 7)

Finally Baetens Beardsmore points to the fact that some postnominal adjectives occur in prenominal position, as in (34), which could be due to influence of Dutch. The same phenomenon is reported for Alsatian French, see (35).

(34) un panier de sale linge

a basket of dirty laundry

"A basket of dirty laundry."

(Vekemans 1963: 36, in Baetens Beardsmore 1971: 137)

(35) Un neuf sac (Wolf 1983: 189)

A new bag

"A new bag." 
In French many adjectives can occur prenominally, however, especially if one wants to obtain special stylistic effects (cf. Wilmet 1986).

\section{Syntactic influence: summary}

French has only marginally influenced the syntax of the Germanic varieties. The basic word order of the main and the subordinate clause remain intact. There appears to be an extension of the possibilities for adjunction in the case of adverbs borrowed from French. These appear in a position to the utmost left of the sentence, but generally not in the position preceding the finite verb. Furthermore an extension in the usage of Dutch van (of) to a variety of constructions can be attributed to French influence.

Syntactic influence in the opposite direction appears to be more extensive. German and Dutch influence is felt to be responsible for the fronting of constituents in Brussels French and - but to a lesser extent - in Alsatian French. Also the occurrence of modal particles such as une fois (some time) in French can be traced back to influence from the Germanic varieties. Not all phenomena described in the (prescriptivist) literature appear to be present in actual spoken language. The majority of the phenomena found in spontaneous data are extensions of existing patterns, which are sometimes found back in other varieties of 
French. The general impression one obtains from the data and the available literature is therefore that no major typological changes have occurred in French as spoken in Strasbourg or Brussels. The Strasbourg data do not contain examples of sentences containing direct objects to the left of French verbs. This phenomenon, which Wolf (1983) presents as a characteristic of Alsatian French, could be indicative of more important changes in the basic word order in Alsatian French. But so far there is no evidence of this phenomenon in corpora of spoken language from either Strasbourg or Brussels.

\section{Discussion}

The overview given here confirms the hypotheses formulated in section 1. Brussels Dutch and Alsatian mainly borrow lexical items from French, whereas structural borrowing from French is limited. For Brussels French and Alsatian French, the opposite is true. Lexical borrowing from the Germanic varieties is less important in the French varieties than structural influences from Brussels Dutch and Alsatian. The overall picture thus reveals basic asymmetries between the influences in both directions. It is interesting to note that for Brussels, Baetens Beardsmore (1971: 48) pointed to the existence of asymmetries in French-Dutch language contact, by asserting that "le flamand prend surtout des éléments lexicologiques au français et subit moins d'influence dans sa morphologie ou dans la syntaxe. Le français au contraire, est très marqué dans sa phonétique par la présence du flamand. La syntaxe, la morphologie et la sémantique sont également influencées par des intrusions flamandes.” 
These asymmetries can be predicted and explained with the help of T\&K's framework for contact-induced change. It is well-known that many speakers of Alsatian and Brussels Dutch have experienced language shift in the direction of the prestige language French. As a matter of fact, there are few monolingual speakers of either Brussels Dutch or Alsatian left. As a result of the process of language shift, French as spoken in Brussels and Strasbourg is typically marked by substrate (and adstrate) influence of the Germanic varieties. This influence becomes apparent in phonology and syntax rather than in the lexicon, as predicted by T\&K.

The Germanic varieties have borrowed extensively from French. This is in line with Bloomfield's observation that "borrowing goes predominantly from the upper language to the lower" (Bloomfield 1933: 461). It comes as no surprise that the lexicon is heavily influenced by French, because, as T\&K (1988: 37) put it: "in a borrowing situation, the first foreign elements to enter the borrowing language are words."

The Germanic varieties have exerted lexical influence on French through loan shifts (Weinreich 1953) rather than through lexical borrowing. Thus, Dutch and Alsatian words and expressions substitute their French equivalents without the actual importation of lexical items from the Germanic varieties. This phenomenon is a well-known process in L2 learning (cf. Kellerman 1986) and it is thus not surprising to find it in a situation of language shift. T\&K do not go into this aspect of lexical influence in their book, although it is an additional typical characteristic of shift-induced interference in my view.

Structural borrowing in Brussels Dutch and Alsatian is limited to relatively minor phenomena. Phonological, morphological and syntactic influence is mainly visible in the 
words borrowed from French. French phonemes only appear in French borrowings, but not in native words, and derivational suffixes from French are not attached to Germanic roots. On the level of syntax, we have seen that the specific position reserved for French adverbs is mainly accessible for French borrowings, and hardly for native adverbs. Only in the extension of the use of van (of) has the influence of French become apparent in Dutch structures. This is however a very peripheral phenomenon. The basic syntax of Alsatian and Brussels Dutch has remained unaffected by French.

Phonological influence from the Germanic varieties in French, on the contrary, is not confined to lexical borrowings from Alsatian and Brussels Dutch. French as spoken in Alsace is clearly marked by the Alsatian phonological system, and Brussels French is undoubtedly marked by Dutch phonological rules. On the level of syntax we have seen that constituents can be placed in the position before the subject. This occurs in sentences, which do not contain any lexical item from either Dutch or German. Thus, whereas structural influence in the Germanic varieties is clearly linked to lexical borrowing, structural interference in the French varieties is not connected to lexical borrowing at all. This confirms T\&K's (1988: 114-115) prediction that "while borrowed morphosyntactic structures are more often expressed by actual borrowed morphemes, morphosyntactic interference through shift more often makes use of reinterpreted and/or restructured TL morphemes." (TL = target language JTD).

$\mathrm{T} \& \mathrm{~K}$ correctly predict that interlingual influences in the domain of inflectional morphology remain limited in comparison to influences on the level of syntax and phonology. This can be explained through the fact that inflectional morphology is a highly structured and 
cohesive part of the grammar. There is no evidence of morphological influences in either Brussels French or Alsatian French.

It is quite remarkable that lexical borrowing is restricted to level 2 (and some aspects of level 3) in Brussels and Strasbourg. Given the fact that the inhabitants of both cities have experienced strong cultural pressure from French, one would have expected to find more intimate forms of borrowing. T\&K suggest that the presence of a standard language related to the borrowing language may constrain the borrowing process. In the Brussels case, this is not unlikely, as standard Dutch has gained importance in the city, as we have seen above. But we need to keep in mind that the majority of the older informants from the inner city of Brussels did not know standard Dutch, and were hardly able to understand it, due to the differences in the phonological systems of Brussels Dutch and standard Dutch. In Treffers-Daller (1992) I have shown that code-switching is less frequent among informants who master standard Dutch and more frequent among speakers who do not know standard Dutch. Thus, for Brussels there is some evidence that the presence of a standard language related to the borrowing language constrains aspects code-switching, and maybe also borrowing. In Strasbourg, on the other hand, standard German hardly plays a role in everyday life. Thus, it is unlikely that the presence of a standard language has had a constraining influence on the borrowing process in Strasbourg.

It is interesting to briefly compare the situation in Brussels and Strasbourg with the situation in South Tyrol and in East Belgium, because the outcome of language contact is very similar in all these areas. According to Riehl (1996) borrowing is also limited to level 2 in the local varieties of German spoken in South Tyrol (in contact with Italian) and East 
Belgium (in contact with French). There are only incidental examples of phenomena belonging to level 3 in those areas. This means that lexical borrowing found in a number of Romance-Germanic contact situations is very similar, despite the sociolinguistic differences between the speech communities. This indicates that sociolinguistic factors may not have been the crucial determinant in the borrowing process in Romance-Germanic contact.

\section{Conclusion}

This paper has shown that the outcome of language contact in Brussels and Strasbourg is strikingly similar, both from a quantitative and from a qualitative point of view. It is hardly possible to explain these similarities with the help of the macro-sociolinguistic factors discussed here, in view of the sociolinguistic differences between both cities. In earlier papers (Treffers-Daller 1997 and in press) I have shown that a number of qualitative differences between the code-switching patterns in Brussels and Strasbourg can be explained on the basis of structural factors alone, and that sociolinguistic factors are unlikely to offer a satisfactory explanation of the facts. The analysis given here should not be interpreted as a claim that sociolinguistic factors do not have a bearing upon language contact at all. It is evident from the literature that the factors discussed here as well as micro-sociolinguistic factors do have influence on the type and frequency of language contact. The point I have tried to make here is that sociolinguistic factors are of little help in explaining the similarities between the contact patterns in Strasbourg and Brussels. The similarities in the outcome of language 
Jeanine Treffers-Daller

contact find a plausible explanation in the fact that the contact situations are typologically similar. Thus, the facts described in this and previous papers (Treffers-Daller 1997 and in press) lend support to the claim that structural factors rather than sociolinguistic factors are the primary determinants of the linguistic outcome of language contact. 


\section{References}

Appel, R. \& Muysken, P. (1987). Language contact and bilingualism. London: Edward Arnold.

Baetens Beardsmore, H. (1971). Le français régional de Bruxelles, Université Libre de Bruxelles, Institut de Phonétique, conférences et travaux 3. Bruxelles: Presses Universitaires de Bruxelles.

Blampain, D. \& Goosse, A. \& Klinkenberg, J.-M. \& Wilmet, M. (1997). Le français en Belgique. Louvain-la-Neuve. Duculot: Ministère de la Communauté française de Belgique (Service de la langue française).

Blanche-Benveniste, C. \& Bilger, M. \& Rouget \& Van den Eynde, C.K. (1990). Le français parlé. Paris: Editions du centre national de la recherche scientifique.

Bloomfield, L. (1933). Language. New York.

Boileau, J. (1946). Le problème du bilinguisme et la théorie des substrats. Revue des Langues Vivantes, XII, 169-193.

Bothorel-Witz, A. \& Huck, D. (1996). Entre savoir et imaginaire. In J. Fritsch (ed.), Le dialecte malgré tout. Saisons d'Alsace, 49 (133), 41-52. Strasbourg: Editions La Nuée Bleue.

Cadiot, P. (1980). Situation linguistique de la Moselle germanophone: un triangle glossique. In: P. Nelde (ed.), Sprachkontakt und Sprachkonflikt, pp. 325-334. Wiesbaden: Harrassowitz. Clyne, M.G. (1987). Constraints on code-switching: how universal are they? Linguistics, 25, 739-764. 
Jeanine Treffers-Daller

Coetsem, F. van (1988). Loan phonology and the two transfer types in language contact. Publications in Language Sciences 27. Dordrecht: Foris.

Cole, R.L. (1975). Divergent and convergent attitudes towards the Alsatian dialect. Anthropological Linguistics, 17 (6), 293-304.

Cron, J. (1902). Supplément de la grammaire française pour l'Alsace ou recueil des fautes que l'on commet le plus et des règles que l'on observe le moins dans le français alsacien. Strasbourg: B.Herder

De Clerck, W. (1981). Zuidnederlands woordenboek. Den Haag, Antwerpen: Martinus Nijhoff.

Denis, M.-N. \& Veltman, C. (1989). Le déclin du dialecte alsacien. Strasbourg: Association des publications près les Universités de Strasbourg.

Deprez, K. \& Persoons, Y. (1984). On the ethnolinguistic identity of Flemish high school students in Brussels. Journal of Language and Social Psychology, 3 (4), 273-294.

De Vriendt, S. (1988). Thème-rhème et contraintes syntaxiques dans le français bruxellois. In:

S. Karolak (ed.), Structure thème-rhème dans les langues romanes et slaves, pp. 65-77. Polska Akademika Nawk.

De Vriendt, S. \& Willemyns, R. (1987). Linguistic Research in Brussels. In E.Witte \& H. Baetens Beardsmore (eds.), The interdisciplinary study of urban bilingualism, pp. 195-231. Clevedon Philadelphia: Multilingual Matters.

De Vriendt, S. \& Goyvaerts, D. (1989). Assimilation and sandhi in Brussels. Leuvense Bijdragen, 78 (1), 1-93. 
De Vriendt, S. \& Van de Craen, P. (1990). Bilingualism in Belgium: a History and an Appraisal. Unpublished Working Paper.

Gardner-Chloros, P. (1985). Choix et alternance des langues à Strasbourg. Thèse pour l'obtention du doctorat en psychologie. Strasbourg: Université Louis Pasteur. Strasbourg 1.

Gardner-Chloros, P. (1991). Language selection and switching in Strasbourg. Oxford: Clarendon Press.

Hanse, J. \& Doppagne, A. \& Bourgeois-Gielen, H. (1974). Nouvelle chasse aux belgicismes. Bruxelles: Fondation Charles Plisnier.

Hanse, J. \& Doppagne, A. \& Bourgeois-Gielen, H. (1987). Chasse aux belgicismes. Bruxelles: Fondation Charles Plisnier.

Hartweg, F. (1983). Tendenzen in der Domänenverteilung zwischen Dialekt und nichtdeutscher Standardsprache am Beispiel des Elsaß. In W.Besch \& U. Knoop \& W. Putschke \& W.E.Wiegand (eds.), Dialektologie. Ein Handbuch zur deutschen und allgemeinen Dialektforschung, pp. 1428-1443. Berlin/New York: Walter de Gruyter.

Hartweg, F. (1985). Die Entwicklung des Verhältnisses von Mundart, deutscher und französischer Standardsprache im Elsaß seit dem 16. Jahrhundert. In W.Besch \& O. Reichmann \& S. Sonderegger (eds.). Ein Handbuch zur Geschichte der deutschen Sprache und ihrer Erforschung, pp. 1949-1977. Berlin/New York: Walter de Gruyter.

Haugen, E. (1950). The analysis of linguistic borrowing. Language, 26, 210-231.

Hawkins, R. (1993). Regional variation in France. In C.Sanders (ed.), French today: Language in its social context, pp. 55-84. Cambridge: Cambridge University Press. 
Huck, D. and Bothorel-Witz, A. (1991). Zur Mehrsprachigkeit im Elsaß. In: B.Thum \& G.-L. Fink (eds.), Praxis Interkultureller Germanistik, pp. 447-460. München: iudicum.

Kellerman, E. (1986). An eye for an eye: crosslinguistic constraints on the development of the L2 lexicon. In E. Kellerman \& M. Sharwood-Smith (eds.), Crosslinguistic influence in second language acquisition, pp.35-48. New York etc.: Pergamon Institute of English.

Kloss, H. (1977). Über einige Terminologie-Probleme der interlingualen Linguistik. Deutsche Sprache, 3, 224-237.

Louckx, F. (1978). Linguistic ambivalence of the Brussels indigenous population. International Journal of the Sociology of Language, 15: 53-60

Louckx, F. (1987). Ethnolinguistic enclosure patterns in post-war Brussels: A sociological analysis. In E. Witte \& H. Baetens Beardsmore (eds.), The interdisciplinary study of urban bilingualism in Brussels, pp. 75-122. Clevedon: Multilingual Matters.

Matzen, R. (1985). Les emprunts du dialecte alsacien au français. In G.-L.Salmon (ed.), Le français en Alsace, pp. 61-68. Paris/Genève: Champion-Slatkine.

McRae, K.D. (1986). Conflict and compromise in multilingual societies, Volume 2. Belgium. Myers-Scotton, C.M. (1990). Constructing the frame in intrasentential codeswitching, Paper prepared for the Annual Meeting, Societas Linguistica Europaea, Bern, Switzerland, September 18-21,1990.

Nadasdi, T.J (1989). Deviation et simplification linguistique dans le français bruxellois. Journal of the Atlantic Provinces Linguistic Association, 11: 1-18.

Nelde, P.H. (1983). Language contact and language shift in Brussels. Folia Linguistica Historica, 4, 101-117. 
Ott, J. and Philipp, M. (1993). Dialekt und Standardsprache im Elsass und im germanophonen Lothringen. Deutsche Sprache, 21 (1), 1-21.

Philipp, M. (1964). Transfert du système phonologique de Blaesheim sur une autre langue, le français. In H.G.Lunt (ed.), Proceedings of the Ninth International Congress of Linguists. Cambridge, Mass., August 27-31, 1962, pp. 392-397. London, The Hague, Paris: Mouton \& Co.

Philipp, M. (1967). La prononciation du français en Alsace. La Linguistique, 1, 63-74.

Philipp, M. (1985). L'accent alsacien, in: G.-L.Salmon (ed.) Le français en Alsace, pp. 19-26. Paris: Champion-Slatkine.

Philipp, M. \& Bothorel-Witz, A. (1989). Low Alemannic. In C.U.J. Russ (ed.) The dialects of modern German: a linguistic survey, pp. 313-336. London: Routledge and Kegan Paul.

Philipps, E. (1975). Les luttes linguistiques en Alsace jusqu'en 1945. Griesheim-sur-Souffel: Editions Culture Alsacienne.

Piron, M. (1979). Le français de Belgique. In A.Valdman (ed.), Le français hors de France. pp. 201-221. Paris: Champion.

Poplack, S. \& Meechan, M. (1995). Patterns of language mixture: nominal structure in Wolof-French and Fongbe-French bilingual discourse. In L.Milroy and P.Muysken (eds.). One speaker two languages, pp. 199-232. Cambridge: Cambridge University Press.

Riehl, C. M. (1996). Deutsch-romanische Sprachkontakte: Gemeinsamkeiten der Kontaktphänomene am Beispiel des Deutschen. In N. Boretzky \& W.Enninger \& Th. Stolz (eds.) Areale, Kontakte, Dialekte. Sprache und ihre Dynamik in mehrsprachigen Situationen, pp. 189-206. Bochum: Brockmeyer. 
Russ, C.U.J. (1989). The dialects of modern German: a linguistic survey. London: Routledge and Kegan Paul.

Salmon, G.-L. (ed.) (1985). Le français en Alsace. Paris: Champion-Slatkine.

Sankoff, D. \& Poplack, S. \& Vanniarajan, S. (1990). The case of the nonce loan in Tamil. Language Variation and Change, 2 (1), 71-101.

Stoeckle, R. (1974). Liste des fautes de langue procédant d'interférences du système linguistique de l' alsacien avec le système linguistique du français. Equipe Départementale de Rénovation pédagogique. Strasbourg: CRDP.

Tabouret-Keller, A. (1964). Contribution à l'étude sociologique des bilinguismes. In H.G.Lunt (ed.), Proceedings of the ninth international congress of linguists. Cambridge, Mass., August 27-31, 1962, pp. 612-621. London, The Hague, Paris: Mouton \& Co.

Tabouret-Keller, A. (1985). Classification des langues et hiérarchisation des langues en Alsace. In G.-L.Salmon, (ed.), Le français en Alsace, pp. 11-17. Paris-Genève: ChampionSlatkine.

Tabouret-Keller, A. (1996). Meschung, un idiome inattendu. In J. Fritsch (ed.) Le dialecte malgré tout. Saisons d'Alsace, 49 (133), pp. 69-73. Strasbourg: Editions La Nuée Bleue.

Tabouret-Keller, A. \& Luckel, F. (1981). La dynamique sociale du changement linguistique: quelques aspects de la situation rurale en Alsace. International Journal of the Sociology of Language, 29, 51-66.

Taeldeman, J. (1977). Französisch-flämische Sprachinterferenz in Flandern. In: P.S.Ureland (ed.) Sprachkontakte im Nordseegebiet. Akten des 1. Symposiums über Sprach-kontakt in Europa, pp. 44-66. Mannheim: Niemeyer. 
Thomason, S. (1998 in press). Contact as a source of language change. In: R.D. Janda and B.Joseph (eds.), A handbook of historical linguistics. Oxford: Blackwell.

Thomason, S. G. and Kaufman, T. (1988). Language contact, creolization and genetic linguistics, Berkeley etc.: University of California Press.

Treffers-Daller, J. (1992). French-Dutch codeswitching in Brussels: social factors explaining its disappearance. Journal of Multilingual and Multicultural Development, 13 (1\&2), 143156.

Treffers-Daller, J. (1994). Mixing two languages: French-Dutch contact in a comparative perspective. Berlin: Mouton de Gruyter.

Treffers-Daller, J. (1995). Les effets contrastant de l'emprunt et de l'interférence: similitudes et dissimilitudes entre Bruxelles et Strasbourg. Plurilinguismes (9-10) Les emprunts, 101124.

Treffers-Daller, J. (1997). Contact on the linguistic frontier: a comparison between the mutual influences of Germanic and Romance language varieties. In W. Wölck \& A. de Houwer (eds.) Recent studies in contact linguistics, pp. 374-384. Bonn: Dümmler.

Treffers-Daller, J. (in press). Participia in Frans-Nederlands en Frans-Duits taalcontact. To appear in Gramma/TTT in 1998.

Van Velthoven, H. (1987). The process of language shift in Brussels: Historical background and mechanisms. In E. Witte \& H.Baetens Beardsmore (eds.), The interdisciplinary study of urban bilingualism in Brussels, pp. 15-45. Clevedon, Philadelphia: Multilingual Matters.

Vassberg, L. M. (1993). Alsatian acts. of identity: Language use and language attitudes in Alsace. Clevedon etc: Multilingual Matters. 
Veltman, C. \& M.-N. Denis (1988). Usages linguistiques en Alsace: présentation d'une enquête et premiers résultats. International Journal of the Sociology of Language, 74, 71-89.

Wahrig, G. (1986, Neuausgabe). Deutsches Wörterbuch mit einem Lexikon der deutschen Sprachlehre. München: Mosaik Verlag.

Weinreich, U. (1953). Languages in contact. La Haye: Mouton.

Willemyns, R. (1979). Bedenkingen bij het taalgedrag van Vlaamse universiteitsstudenten uit Brussel-Halle-Vilvoorde, Taal en Sociale Integratie, II, 141-160. Brussels: VUB.

Willemyns, R. (1984). La standardisation linguistique en dehors des centres de gravité de la langue: la Flandre et le Québec. In J.F. Hamers \& J.D.Gendron \& R.Vigneault (eds.) Du disciplinaire à l'interdisciplinaire dans l'étude des contacts des langues, pp. 52-70. Québec: CIRB, B-135.

Wilmet, M. (1986). La détermination nominale, quantification et caractérisation. Linguistique nouvelle, PUF.

Witte, E (1987). Bilingual Brussels as an Indication of Growing Political Tensions (19601985). In: Witte, E. \& H. Baetens Beardsmore (eds.), The interdisciplinary study of urban bilingualism in Brussels, pp. 47-76. Clevedon Philadelphia: Multilingual Matters.

Witte, E. \& Baetens Beardsmore, H. (eds.) (1987). The interdisciplinary study of urban bilingualism in Brussels, Clevedon, Philadelphia: Multilingual Matters.

Wolf, L. (1983). Le français régional d'Alsace. Etude critique des alsacianismes. Paris: Klincksieck. 
Notes

${ }^{1}$ I am very grateful to Penelope Gardner-Chloros for having allowed me to study her corpus from Strasbourg. I have benefited from the extensive and detailed comments of Lesley Milroy, Pieter Muysken, Sarah Thomason and Sera de Vriendt on previous versions of this article. I also received important comments from Hugo Baetens Beardsmore, Kate Beeching, Penelope Gardner-Chloros, Susan Price, Gisela Shaw and Andrée Tabouret-Keller. While all of them helped make this article a better one, they cannot be held responsible for any defects that remain.

2 In 1998 Thomason revises the model slightly in that she points out that "the crucial factor is not whether or not shift takes place, but whether or not there is imperfect learning by a group of people."

3 The data from Strasbourg were collected between 1981 and 1985 and the data from

Brussels between 1985 and 1990. Although the corpora differ in size, we believe there is a sufficient basis for the comparison of both data sets.

4 Translation: "Languages for which a standard variety exists in other countries but whose speakers in the country under investigation do not know this standard variety anymore or (less often) not yet."

5 INSEE: Institut National de la Statistique et des Etudes Economiques .

${ }^{6}$ According to Hartweg (1983) the respondents were 3000 families that are considered to be representative for the entire population of Alsace, as well as 3000 individuals over fifteen years of age.

I counted all instances of single French words in Alsatian discourse and all instances of single Alsatian words in French discourse. Compound nouns are included among the nouns, but switches of other frozen multi-word expressions are not included in these counts. I included occurrences of morphonologically integrated French verbs such as (confirmiere - to confirm) in Alsatian discourse in the counts.

8 Kate Beeching draws my attention to the fact that in standard French one generally uses sur and not par in the expression quatre-vingt-dix sur cent. The origin of French par in negentig par honderd is thus rather mysterious.

9 Vis-à-vis is probably an established loan in German, as it is given by Wahrig (1986) as equivalent of German gegenüber (opposite). Wahrig considers vis-à-vis to be an adverb and only gives examples of adverbial uses of this expression.

10 I am grateful to Sera de Vriendt for having provided me with this example. 
11 This example was found in the speech of Gust (tape 7: 25). Contrary to the situation described for the Alsatian example, in the Brussels case, a French word has been imported into Brussels Dutch, namely attentie (attention).

12 Bilingual and monolingual speakers may not recognise all French lexemes in these compounds as French words, but this fact - however important - cannot be discussed in detail in this paper.

13 The meaning of the expression is not entirely clear, as it is said in the context of a joke which remains unexplained. It occurs in conversation B, is produced by René, p 13).

14 It is not clear whether the first or the second half of this compound has primary stress, and therefore it cannot be determined whether this compound is entirely comparable to the ones described above under pattern 3 .

15 The hyphen indicates the separation between the two lexical items that form the compound. This hyphen is not present in the spelling Hartweg gives of the compounds. We have adopted Hartweg's spelling in that the compounds are written with a capital letter, as is normally the case in German. Hartweg does not give a German translation of these compounds and it is difficult to find translation equivalents in English for these terms because of cultural and administrative differences between France, Germany and English-speaking countries.

16 There is variability in the pronunciation of many loanwords, as we can see in the pronunciation of interessant (interesting), which occurs in my corpus as [\$*nt\$4r\$3s\$3nt and as [\$*nt\$4r\$3sant. This variability has not yet been studied.

17 Thomason points to the fact that it is remarquable that the final $-t$ is pronounced in ambetant. It is very well possible, as Thomason suggests, that the feminine form of the adjective is at the origin of this form, as the $-t$ is pronounced in the feminine version of the article. Alternatively Thomason suggests that spelling pronunciation is responsible for the $-\mathrm{t}$.

18 In Standard French, the distinction between $/ \$ 7 /$ and $/ \$ 8 /$ is disappearing, but in Belgian French the two nasal vowels are still distinguished (Blampain, Goose, Klinkenberg and Wilmet 1997).

19 Thomason (p.c.) suggests that spelling pronunciation may be an additional factor explaining the pronunciation of the $-\mathrm{s}$.

20 In the case of non-gradable adjectives, meer can be interpreted as indicating a quantity rather than a quality. Thus, in (10) meer Vlaams probably means that there are more inhabitants in Molenbeek who are able to speak Flemish than elsewhere in Brussels. 21 The use of $\mathrm{om}$ is not obligatory, especially in written language. 